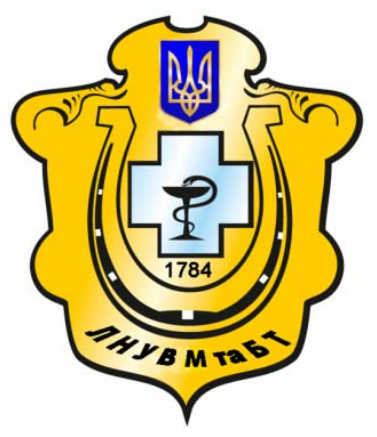

Науковий вісник Львівського національного університету ветеринарної медицини та біотехнологій імені С.3. Гжицького

Scientific Messenger of Lviv National University of Veterinary Medicine and Biotechnologies named after S.Z. Gzhytskyj

doi:10.15421/nvlvet6635

ISSN 2413-5550 print

ISSN 2518-1327 online

$\underline{\text { http://nvlvet.com.ua/ }}$

УДК 619:612. 017:636.3.084

\title{
Кількісний склад мікробіоти кишечника поросят у різні періоди стресу-відлучення на тлі використання добавок «В-глюкан» та «Біовір»
}

\author{
В.Г. Стояновський, О.І. Мацюк, В.А. Колотницький, І.А. Коломієць \\ kolviktor1980@gmail.com
}

Львівський національний університет ветеринарної медицини та біотехнологій імені С.3. Гжицького, вул. Пекарська, 50, м. Львів, 79010, Украӥна

\begin{abstract}
У статті наведено результати дослідження кількості основних представників мікробіоти (лакто- та біфідобактерій, кишкової палички, бачил) кишечника поросят у період відлучення на 28 добу життя (за дії стресу), а також у різні періоди розвитку стадії резистентності (через 20 та 60 діб після відлучення) за включення в раціон пробіотичних добавок «Bглюкан» та «Біовір». Установлено кількісну характеристику основних представників мікрофлори тонких та товстих кишок поросят К групи на 28 добу життя, щчо є ознакою сформованого мікробіоченозу, клінічно здорових тварин та вказує на достатній рівень адаптаційних реакиій їх організму. За дії стресу відлучення на стадії резистентності (через 20 та 60 діб після відлучення) адаптачія основних представників мікрофлори кишечника поросят К групи супроводжується зниженням кількості біфідо- та лактобактерій $і$ зростанням кількості кишкової палички в середньому на два порядки у порожнині та у пристінковому шарі тонких кишок $(p<0,05)$. Згодовування тваринам дослідних груп добавки «В-глюкан» та «Біовір» з 5- до 45-добового віку сприяе підвищенню кількості біфідо- $і$ лактобактерій та позитивній динаміиі кількості кишкової палички у різних відділах кишечника поросят на 28 добу життя, а також через 20 і 60 діб після відлучення, що вказуе на пролонговану дію добавок в організмі поросят за дії стресу. Кращий ефект на активацію механізмів адаптогенезу мікробіоти кишечника поросят за дії стресу проявляла добавка «Біовір».
\end{abstract}

Ключові слова: лактобактерії, біфідобактерії, кишкова паличка, мікробіота, тонкі кишки, поросята, відлучення, стрес, адаптація, пробіотичні добавки.

\section{Количественный состав микробиоты кишечника поросят в разные периоды стресса-отьема на фоне применения добавок «В-глюкан» и «Биовир»}

\author{
В.Г. Стояновский, О.И. Мацюк, В.А. Колотницкий, И.А. Коломиец \\ kolviktor1980@gmail.com
}

\begin{abstract}
Львовский национальный университет ветеринарной медицины и биотехнологий имени С.3. Гжицкого, ул. Пекарская, 50, г. Львов, 79010, Украина
\end{abstract}

В статье приведены результаты исследования количества основных представителей микробиоты (лакто- и бифидобактерий, кишечной палочки, бачилл) кишечника поросят в период отъема на 28 сутки жизни (за действия стресса), а также в различные периоды развития стадии резистентности (через 20 и 60 суток после отъема) при включение в рацион пробиотических добавок «В-глюкан» $и$ «Биовир». Установлено количественную характеристику основных представителей микрофлоры тонкого и толстого кишечника поросят К группы на 28 сутки жизни, что является признаком сформированного микробиоченоза, клинически здоровых животных и указывает на достаточный уровень адаптационных реакций их организма. За действия стресса отъема на стадии резистентности (через 20 и 60 суток после отъема) адаптаиия основных представителей микрофлоры кишечника поросят К группы сопровождается снижением количества бифидо- и лак-

Citation:

Stojanovskyj, V.G., Matsjuk, O.I., Kolotnytskyy, V.A., Kolomijets, I.A. (2016). Quantitative composition of the microflora of piglets intestinal in different periods of stress weaning under the using of additives «B-glucan» and «Biovir». Scientific Messenger LNUVMBT named after S.Z. Gzhytskyj, 18, 2(66), 176-179. 
тобактерий и ростом количества кишечной палочки в среднем на два порядка в полости и в пристеночном слое тонкого кишечника $(p<0,05)$. Скармливания животнылм опьтнных групп добавки «В-глюкан» и «Биовир» с 5 до 45-суточного возраста способствует повышению количества бифидо-и лактобактерий и положительной динамике количества кишечной палочки в разных отделах кишечника поросят на 28 сутки жизни, а также через 20 и 60 суток после отъема, что указывает на пролонгированное действие добавок в организме поросят за действия стресса. Лучший эффект на активацию механизмов адаптогенезу микробиоты кишечника поросят за действия стресса проявляла добавка «Биовир».

Ключевые слова: лактобактерии, бифидобактерии, кишечная палочка, микробиота, тонкий кишечник, поросята, отъем, стресс, адаптация, пробиотические добавки.

\title{
Quantitative composition of the microflora of piglets intestinal in different peri- ods of stress weaning under the using of additives «B-glucan» and «Biovir»
}

\author{
V.G. Stojanovskyj, O.I. Matsjuk, V.A. Kolotnytskyy, I.A. Kolomijets \\ kolviktor1980@gmail.com \\ Lviv National University of Veterinary Medicine and Biotechnologies named after S.Z. Gzhytskyi, \\ Pekarska Str., 50, Lviv, 79010, Ukraine
}

The article presents data of the results of the study the number of the main representatives of the intestine microflora (lakto-and bifidobacteria, E. coli, bacillus) of pigs during the weaning at 28 days of life (by the action of stress) and in different periods of development stage resistance (20 and 60 days after excommunication) for inclusion in the diet of probiotic supplements «B-glucan» and «Biovir». It is established a quantitative description of the main representatives of the microflora of small and large intestines of pigs $K$ group at 28 days of life, a sign of the prevailing microbiota clinically healthy animals and points to the sufficient level of adaptation reactions of the organism. Under the action of stress at weaning stage resistance (20 and 60 days after weaning) adaptation of the main representatives gut of piglets $K$ associated with lower number of bifidobacteria and lactobacilli and increasing number of E. coli average of two orders in the cavity in the wall and the thin layer of the intestines $(p<0,05)$. Feeding animal research groups additives «B-glucan» and «Biovir» of 5- to 45-day age contributes to the number of bifidobacteria and lactobacilli and positive dynamics of the number of E. coli in different parts of the intestine of pigs at 28 days of life and 20 and 60 days after weaning, indicating a prolonged effect of additives in the body for action piglets stress. The best effect for activation of mechanisms of adaptogenesis of piglets intestinal microbiota is showed additive «Biovir» for the actions of stress.

Key words: lactobacillus, bifidobacteria, E. coli, microflora, small intestine, piglets, weaning, stress, adaptation, probiotic supplements.

\section{Вступ}

Найважливішою проблемою раннього відлучення поросят від свиноматки є забезпечення біологічної адаптації їх організму до нових умов утримання, мікроклімату, а також зниження стресових навантажень у період відлучення при переході на новий тип живлення, що обумовлює зміни кількісного та якісного складу мікрофлори кишечника поросят i $\epsilon$ етіологічним фактором розвитку кишкового дисбіозу (Holyk, 2000; Danchuk, 2000; Denysiuk, 2008; Kandyba et al., 2008). 3 метою профілактики розладів ШКТ в період відлучення доведено ефективність застосування пробіотичних добавок в раціонах поросят промислового вирощування (Mazurenko, 2005; Subbotyn, 2007; Shumylov, 2007). Обгрунтування диференційованого підходу організації відгодівлі поросят з включенням біологічно активних добавок можливе за умови комплексного дослідження динаміки становлення мікробіоти кишечника поросят у різні періоди розвитку стресу-відлучення. Як відомо, в кишечнику представники нормальної мікрофлори знаходяться у вигляді двох форм - одна частина розташовується в просвіті ШКТ (мікрофлора порожнинна); інша, вкрита мукозним пристінковим матриксом, утворює біоплівку або так званий «бактеріальний дерен» (пристінкова або мукозна мікрофлора), який є більш стійкий до адгезії патогенними мікроорганізмами (Mazurenko, 2005; Subbotyn, 2007). Метою нашої роботи було дослідити кількісний склад основних представників мікробіоти, які функціонують у порожнині та у пристінковому шарі клубової, сліпої, ободової кишки поросят у процесі адаптації організму до стресу-відлучення при використанні пробіотичних добавок «В-глюкан» та «Біовір».

\section{Матеріал і методи досліджень}

Досліди проведені в умовах ННВЦ «Давидівський» Львівського національного університету ветеринарної медицини та біотехнологій імені С.3. Гжицького на клінічно здорових поросятах 5-90добового віку полтавської білої породи. Для досліджень було сформовано три групи поросят - контрольна (К) і дві дослідні (Д, Д 2 ), у кількості 10 особин у кожній групі. 3 5- до 45-добового віку поросятам Д 1 групи згодовували кормову добавку «Вглюкан», Д 2 групи - кормову добавку «Біовір» у кількості 10 мг/кг маси тіла на добу. На 28 добу життя поросят відлучали від свиноматки. Матеріалом для досліджень слугували відрізки тонких та товстих кишок разом із вмістом, які відбирали після легкого наркозу та декапітації у трьох тварин на 28 добу життя (відлучення), на 48 добу життя (20 доба після відлучення), на 88 добу життя (60 доба після відлучення). У вмісті порожнини та у пристінковому шарі слизової оболонки клубової, сліпої, ободової кишки визначали кількість лакто-, біфідобактерій, кишкової палички та бактерій роду Bacillus - за загальновизнаними методиками (Tarakanov, 1998). Визначали 
ступінь вірогідності різниці (р) між досліджуваними показниками поросят $\mathrm{K}$ i Д 1 , Д 2 груп за допомогою програми Statystika для Windows XP з використанням $\mathrm{t}-$ критерію Стьюдента. При виконанні експериментальних досліджень дисертаційної роботи всі маніпуляції з поросятами, які були задіяні в експерименті, проводили згідно 3 Європейською конвенцією «Про захист хребетних тварин, які використовуються для експериментальних і наукових цілей» (Страсбург, 1986 р.) і «Загальних етичних принципів експериментів на тваринах», ухвалених Першим Національним конгресом з біоетики (Київ, 2001) та дотриманням принципів гуманності, викладеними у директиві Свропейської Спільноти (Directive 2010/63/eu of the european parliament and of the council of 22 September 2010 on the protection of animals used for scientific purposes. Official Journal of the European Union L276/33. 86/609/EC. 20. 10. 2010.).

\section{Результати та їх обговорення}

За результатами отриманих досліджень було встановлено, що на 28 добу життя (період відлучення) у порожнині клубової кишки поросят К групи кількість біфідобактерій складала 8,02 $\pm 0,37 \lg \mathrm{KУO} / г$, у Д групі, на тлі згодовування кормової добавки «Вглюкан», іiі величина збільшувалася на 30,4\% (p < 0,05), у Д г групі, на тлі кормової добавки «Біовір», залишалася на рівні величин К групи тварин. Кількість лактобактерій у даній кишці поросят К групи складала 7,09 \pm 0,61 lg КУО/г, а у поросят Д 1 і Д 2 груп була більшою в середньому на $27,8 \%(\mathrm{p}<0,05)$. У пристінковому шарі слизу цієї кишки поросят К групи кількість біфідо- і лактобактерій складала 7,60 \pm 0,21 та 7,56 \pm 0,02 $\mathrm{lg} \mathrm{KУО/г,} \mathrm{у} \mathrm{поросят} \mathrm{Д} 1$ групи була більшою на $37,6 \%$ i $30,0 \%(\mathrm{p}<0,05)$, а у поросят Д2 групи - на 23,7\% (p < 0,05) і 42,1\% (p < 0,01) відповідно. У порожнині та у пристінковому шарі слизу сліпої кишки поросят К групи кількість біфідобактерій складала 7,45 \pm 0,21 i 6,89 $\pm 0,57 \mathrm{lg} \mathrm{KУO} / г$, у Д групі вона зростала на $45,8 \%(\mathrm{p}<0,01)$, а у Д2 групі була вища на порядок, порівняно з контролем. Кількість порожнинних і пристінкових лактобактерій в сліпій кишці поросят К групи знаходилася в межах 6,63 $\pm 0,40-6,70$ $\pm 0,30 \mathrm{lg} \mathrm{KУО/г,} \mathrm{у} \mathrm{поросят} \mathrm{Д} \mathrm{групи} \mathrm{була} \mathrm{більшою} \mathrm{на}$ $51,2 \%$ i $42,2 \%,(\mathrm{p}<0,01)$, а у поросят Д 2 групи - на 21,3\% і 14,0\% (p < 0,05) відповідно. Кількість кишкової палички у порожнині та у пристінковому шарі слизу сліпої кишки поросят К і Д груп коливалася в межах 5,60 $\pm 0,30-6,66 \pm 0,07 \mathrm{lg} \mathrm{KУO} / г$, а у Д 2 групі вона збільшувалась на $38,6 \%(\mathrm{p}<0,05)$. У порожнині та у пристінковому шарі ободової кишки поросят $\mathrm{K}$ групи кількість біфідобактерій перебувала в межах $7,27 \pm 0,67-7,87 \pm 0,60 \lg \mathrm{KУО} / г$, у поросят Д 1 та Д 2 груп зростала в середньому на $34,8 \%(\mathrm{p}<0,05)$ i $24,5 \%(\mathrm{p}<0,01)$. У порожнині ободової кишки поросят К групи кількість лактобактерій складала 8,37 0,70 lg КУО/г. У Д групі їх величина збільшувалась на 21,4\% ( $<0,05)$, тоді як у Д2 групі тварин залишалася без вірогідних змін. Натомість, у пристінковому шарі слизу виявлено зростання кількості лактобактерій у поросят Д 2 групи на $31,1 \%(\mathrm{p}<0,05)$, порівня- но 3 контролем. Кількість порожнинної кишкової палички у поросят К групи складала 7,43 $\pm 0,51 \mathrm{lg}$ КУО/г, з аналогічними величинами у поросят Д 1 групи, при цьому у Д г групі вона знижувалась проти К групи на $30,9 \%(\mathrm{p}<0,05)$. У пристінковому шарі ободової кишки, порівняно 3 порожниною, кількість кишкової палички поросят К групи була нижчою, i складала 4,01 $\pm 0,27 \mathrm{lg} \mathrm{KУO} / г$, проте у поросят Д 1 і Д груп вона збільшувалась в середньому на $33,7 \%$ (p < 0,05), порівняно з К групою тварин.

На 20 добу розвитку стресу відлучення у порожнині клубової кишки поросят К групи кількість біфідо- та лактобактерій знижувалася на два порядки $(\mathrm{p}<0,05)$, тоді коли кількість кишкової палички зростала до $5,74 \pm 0,63 \mathrm{lg} \mathrm{KУO} / г$, порівняно з 28 добою життя. На стадії резистентності у пристінковому шарі мукози клубової кишки тварин К групи знижувалася на два порядки кількість лактобактерій, збільшувалася на чотири порядки кількість кишкової палички, порівняно з 28 добою життя, а кількість бацил залишалася на рівні періоду відлучення (28 доба життя). Адаптація мікробіоти порожнини клубової кишки поросят Д 1 і Д груп характеризувалася збільшенням кількості лактобактерій на 21,9\% (p < 0,05) i 41,9\% (p $<0,01)$, бактерій роду Bacillus - на 67,0\% і 58,5\% (p < 0,01) відповідно, при зменшенні кількості кишкової палички на $16,4 \%$ та 23,6 \% p < 0,05), порівняно 3 контролем. У порожнині сліпої кишки адаптивні зміни біфідобактерій у тварин Д 1 і Д 2 груп характеризувалися вірогідним зростанням їх кількості відповідно на 19,3\% (p < 0,05) і 35,3\% (p < 0,01), при цьому кількість лактобактерій - перебувала на рівні контрольних величин у поросят Д 1 групи, проте зростала на $37,5 \%(\mathrm{p}<0,05)$ у Д 2 групі тварин, порівняно 3 контролем. Кількість базисних (пристінкових) біфідоі лактобактерій у сліпій кишці тварин Д групи збільшувалася в середньому на 28,0\% (p < 0,05), а у Д групі - на 54,8\% (p < 0,01), відносно величин К групи тварин. У порожнині та у пристінковому шарі ободової кишки поросят Д групи кількість біфідобактерій зростала відповідно на 15,6\% (p<0,05) і 23,5\% (p < $0,01)$, а у Д2 групі - на $37,0 \%(\mathrm{p}<0,01)$ i $19,8 \%(\mathrm{p}<$ $0,05)$, порівняно з контролем. Кількість лактобактерій вірогідно зростала на 19,0\% та $17,7 \%(\mathrm{p}<0,05)$ лише у пристінковому шарі ободової кишки поросят Д 1 і Д груп, при цьому кишкова паличка збільшувалась на 49,9\% (p < 0,01) і 16,2\% (p< 0,05) відповідно, порівняно з контролем. Бактерії роду Bacillus у просвіті ободової кишки поросят контрольних груп знижувалися в середньому на $18,3 \%(\mathrm{p}<0,05)$, а у пристінковому шарі збільшувалися в середньому на 29,1\% (p < 0,05), порівняно з К групою тварин.

На 60 добу розвитку стресу не спостерігали тенденцію до збільшення кількості окремих мікроорганізмів (біфідо- і лактобактерій) кишечника поросят К групи, їх числові значення не наближалися до величини цих показників поросят на 28 добу життя. Адаптація основних представників мікробіоти тонких i товстих кишок поросят Д 1 і Д 2 груп супроводжувалась збільшенням їх кількості навіть після припинення згодовування застосованих кормових добавок, що може вказувати на їх пролонговану дію в організмі 
тварин. Як виявилось, у даний період стресу кількісний склад біфідо- та лактобактерій у порожнині клубової кишки поросят Д групи зростав на порядок, а у Д групі збільшувався на $24,8 \%(\mathrm{p}<0,05)$ і $22,8 \%$ $(\mathrm{p}<0,05)$ відповідно, порівняно 3 контролем. Кількість кишкової палички у даній кишці поросят дослідних груп коливалася без вірогідних змін в межах величин вихідного періоду. Що стосується бактерій роду Bacillus, то їх кількість у поросят Д і Д груп знижувалася в середньому на 27,1\% (р < 0,05), порівняно $з$ контролем. У пристінковому шарі слизової оболонки клубової кишки виявлено вірогідне збільшення на порядок кількості біфідо- і лактобактерій порівняно 3 контролем лише у поросят Д 2 групи, тоді коли інші представники мікробіоти кишечника знаходилися в межах величин К групи тварин. У порожнині та пристінковому шарі сліпої кишки кількість біфідо- і лактобактерій у даний період стресу збільшувалась відповідно на 29,8\% (p < 0,01) і 32,6\% ( $\mathrm{p}<0,05)$ по відношенню до контролю, лише у поросят Д групи, однак залишалася без вірогідних змін у тварин Д 1 групи.

\section{Висновки}

За дії стресу відлучення кількісна адаптація основних представників мікрофлори кишечника поросят К групи супроводжується зниженням кількості біфідо- та лактобактерій і зростанням кількості кишкової палички в середньому на два порядки у порожнині та у пристінковому шарі тонких кишок на стадії резистентності $(\mathrm{p}<0,05)$. У тварин дослідних груп за дії стресу на різних етапах стадії резистентності кількість нормофлори кишечника збільшується на два порядки ( $<<0,05-\mathrm{p}<0,01)$, що вказує на пролонговану дію добавок в організмі поросят. Кращий ефект на активацію механізмів адаптогенезу мікробіоти кишечника поросят за дії стресу проявляла добавка «Біовір».

Перспективи подальших досліджень. У подальшому планується дослідження кількості осно- вних представників мікробіоти кишечника поросят на ранніх етапах постнатального онтогенезу.

\section{Бібліографічні посилання}

Holyk, M. I. (2000). Profilaktyka stresu v porosiat pry vidluchenni. Zh. «Veterynarna medytsyna». 5, 39-41 (in Ukrainian).

Danchuk, V.V. (2000). Shliakhy pidvyshchennia produktyvnosti svynarstva. Zh. «Tvarynnytstvo Ukrainy». 7-8, 2-3 (in Ukrainian).

Denysiuk, P.V. (2008). Biorytmy u tvarynnytstvi. Svynarstvo. 56, 67-72 (in Ukrainian).

Kandyba, V.M., Chertkov, D.D., Chertkov, B.D. (2008). Priorytetni napriamy pidvyshchennia produktyvnosti svynei i rentabelnosti haluzi svynarstva v Ukraini. Problemy zooinzhenerii ta veterynarnoi medytsyny. Zb. nauk. prats. 16 (41), 167-171 (in Ukrainian).

Mazurenko, M.O. (2005). Morfolohichni osoblyvosti kyshechnyku svynei pry zghodovuvanni kormovykh dobavok. Zb. nauk. prats VDAU. 20, 17-22 (in Ukrainian).

Subbotyn, V.V. (2007). Stanovlenye normalnoho mykrobyotsenoza $\mathrm{V}$ postnatalnom peryode $\mathrm{u}$ domashnykh zhyvotnykh. Materyaly pervoho sjezda farmakolohov Rossyy. 570-575 (in Russian).

Tarakanov, B.V. (1998). Metody issledovanija mikroflory pishhevaritel'nogo trakta sel'skohozjajstvennyh zhivotnyh i pticy [Tekst]. Borovsk: VNIIFBiP s.-h. zhivotnyh (in Russian).

Shumylov, B.V. (2007). Probyotyky-symbyonty vmesto kormovykh antybyotykov $\mathrm{v}$ ratsyone suporosnykh svynei y porosiat-sosunov. Zh. «Efektyvni kormy ta hodivlia». 5(21), 34-35 (in Russian).

Стаття надійшла до редакиії 28.09.2016 